\title{
Research on Active Compounds of Huanglian Jiedu Decoction for the Treatment of Corona Virus Disease 2019 Based on Network Pharmacology and Molecular Docking
}

\section{Leping Liu}

Central South University Third Xiangya Hospital

\section{Xinyi Xu}

Hunan University of Chinese Medicine

\section{Xueshuai Cao}

Hunan university of traditional chinese medicine

Xi Long

Hunan University of chinese medicine

Yanwei Luo

Central South University Third Xiangya Hospital

Rong Gui ( $\square$ aguirong@163.com )

Central South University Third Xiangya Hospital

\section{Research}

Keywords: Active compounds, Huanglian Jiedu Decoction, Corona Virus Disease 2019, SARS-CoV-2, ACE2, Network pharmacology, Molecular docking

Posted Date: July 27th, 2020

DOI: https://doi.org/10.21203/rs.3.rs-45022/v1

License: (1) This work is licensed under a Creative Commons Attribution 4.0 International License. Read Full License 


\section{Abstract}

Background Huanglian Jiedu Decoction (HLJDD) is a traditional Chinese prescription for the treatment of influenza, inflammation and other ailments related to heat-syndrome, a typical pathological symptom in Traditional Chinese Medicine. It was recommended as one of the basic prescriptions among the Proposed Diagnoses and Treatment issued by China's National Health Commission. In this work we investigated the molecular mechanism of action of Huanglian Jiedu Decoction in the treatment of Corona Virus Disease 2019 (COVID-19) through network pharmacology and molecular docking approaches.

Methods The chemical constituents and action targets of Coptis chinensis, Scutellaria baicalensis, Phellodendron amurense, Gardenia jasminoides in HLJDD were retrieved on Traditional Chinese Medicine Systems Pharmacology Database and Analysis Platform (TCMSP). The database of UniProt and GeneCards were used to query the target genes that corresponding to the active compounds, and then a compound-target network was constructed using Cytoscape 3.7.2. GO database was used to annotate GO functions. Reactome was used to analyze KEGG enrichment pathway, predicting the possible mechanisms of active compounds. DAVID database was used to analysis the tissue enrichment. The main active ingredient is molecularly docked with the SARS-CoV-2, ACE2 and TMPRSS2.

Results We screened 84 compounds and obtained 341 corresponding target genes in the network. Gene annotation showed that the targets were involved mainly in 457 biological functions. 306 signaling pathways was enriched, involving chemokine and cytokine signaling pathways that mediate inflammation, interferon- $y$ signaling pathway, p53 pathway. And the targets mainly distributed in the lung liver and placenta, involving a variety of immune cells, such as $T$ cells, B cells. The molecular docking results showed that core compounds such as beta-sitosterol, stigmasterol and quercetin had high affinity with SARS-CoV-2, ACE2 and TMPRSS2, which was comparable with drugs like abidol used to COVID-19 treatment by.

Conclusions The active compounds in HLJDD may have a therapeutic effect on COVID-19 through regulating multiple signal pathways by targeting genes such as VEGF, NOS2, IL6, MMP9, IL10, and TGFB1.

\section{Background}

On December 31, 2019, unidentified pneumonia appeared in the South China Seafood Market in Wuhan, Hubei Province, China. After that, patients with a history of stay in Wuhan and a history of contact with Wuhan personnel have appeared successively throughout the country. On February 11, 2020, the World Health Organization (WHO) named this pneumonia COVID-19. At the same time, the pathogen was named SARSCoV-2. The new type of pneumonia developed rapidly and was extremely contagious [1, 2]. The main clinical symptoms were fever, cough and asthma. Some patients also have gastrointestinal symptoms. Some patients enter the critical stage and develop respiratory failure or even death [3].

In order to fight the epidemic, so far, the National Health Commission and the State Administration of Traditional Chinese Medicine have published 6 versions of a new coronavirus diagnosis and treatment plan. In the protocol, Huanglian Jiedu Decoction (HLJDD) is used to treat patients with the following clinical manifestations: high fever, cough, little sputum, or yellow sputum, chest tightness, shortness of breath, 
bloating and constipation. This prescription is a well-known prescription for treating heat-syndrome in China and was first mentioned in the "WaiTaiMiYao" by a medical scientist who named Wang Tao in the Tang Dynasty. It is an aqueous extract of 4 herbal materials, Coptis chinensis (Huanglian, the rhizomes of Coptis chinensis Franch, Ranunculaceae), Scutellaria baicalensis (Huangqin, the dried roots of S. baicalensis Georgi, Lamiaceae), Phellodendron amurense (Huangbo, the dried bark of Phellodendron amurense Rupr., Rutaceae ), and Gardenia jasminoides(Zhizi, dried ripe fruit of Gardenia jasminoides J.Ellis, Rubiaceae) with the ratio of 3:2:2:3. This formula has been used since ancient times, and has been widely used in clinical practice, and is officially included in the Chinese Pharmacopoeia[4]. In gastrointestinal diseases, inflammation, cardiovascular diseases and Alzheimer's disease, HLJDD has good clinical effects [5-7]. Modern pharmacological studies have also elucidated the pharmacokinetics and pharmacodynamics of HLJDD, and found that the main compounds of iridoids, flavonoids and alkaloids in HLJDD can play an anti-inflammatory effect[8]. Baicalein and coptisine, the active ingredients in Huanglian Jiedu Decoction, interfere with the arachidonic acid cascade by inhibiting the lipoxygenase pathway and exert anti-inflammatory effects [9]. Liu et al. studied the effect of HLJDD on the urine metabolomics of healthy people and found seven potential biomarkers, including 2- (formylamino) -benzoic acid, whicn has proved the mechanism of in treating heat syndrome HLJDD from pharmacology $[1,10]$. In the in vitro study, the modified HLJDD also activated the plasma bactericidal activities [10]. However, the role and mechanism of HLJDD's in COVID-19 are unclear and needs further investigation.

Network pharmacology is a new discipline that combines the functions of drug compounds, disease targets, and biological signaling pathways based on computer network analysis [11,12], which is suitable to analyze the traditional Chinese medicine because of the multiple targets affected by the multi-components. Network pharmacology is able to visualize, systematize, and informatize the principles of the process of treating diseases by traditional Chinese medicine. The molecular docking technology predicts the binding mode and affinity between two molecules by analyzing the physical and chemical properties of the molecules and by computer simulation[13]. Molecular docking plays an important role in the mechanism of active ingredients and target proteins of traditional Chinese medicine. It can clarify the principle of the efficacy of traditional Chinese medicine at the molecular level, making the research of traditional Chinese medicine microscopic and scientific. SARS-CoV-2 crystal structure has been determined by Shanghai Tech University (PDB 6LU7). SARSCoV-2 invades cells by binding the ACE2 receptor on the surface of human cells with the S protein of its spinous. Recently, German scientist Markus Hoffmann discovered that SARS-CoV-2 needs the help of TMPRSS2(Transmembrane Protease Serine 2) protein to enter cells. This article intends to analyze the active ingredients and target genes of HLJDD through network pharmacology, and dock the main active ingredients with SARS-CoV-2 hydrolase, ACE2 and TMPRSS2 to provide a theoretical basis for its clinical application.

\section{Methods}

The workflow is demostrated in Fig. 1.

\section{Collection and screening of components of HLJDD and their corresponding targets}


This research was based on the TCMSP (TCMSP, http://Isp.nwu.edu.cn/ tcmspsearch.php )[14],and the keywords "Scutellaria baicalensis", "Coptis chinensis ", "Phellodendri Chinrnsis Cortex" and "Gardenia jasminoides" were searched to obtain all ingredients. In this study, the oral bioavailability $(\mathrm{OB}) \geq 30 \%$ and drug-likeness $(\mathrm{DL}) \geq 0.18$ were used to screen the components of Scutellaria baicalensis, Coptis chinensis, Phellodendri Chinrnsis Cortex and Gardenia jasminoides to obtain the more active components in TCSMP[15]. Bioavailability refers to the relative amount of drugs that is absorbed into the systemic blood circulation and metabolized after being administered via an extravascular route. Drug-like properties are usually used to evaluate the possible failure characteristics of a compound. The significance of this standard lies in bioavailability. The higher the degree and drug-like properties, the more research significance the human body has. Through the TCMSP platform, the target components are collected in the corresponding target database to obtain the target of the component [16].

\section{Establishing the ingredient-target network}

The collected ingredients and targets are sorted and imported into Cytoscape 3.7.2 software (http://www.Cytoscape.org/)[17] to generate a network of active ingredients-target interactions of HLJDD. Visualize the pharmacological action mechanism of HLJDD.

\section{Target pathway analysis}

In order to further understand the function of the selected target protein genes and the role in the signaling pathway, the target protein obtained after weight reduction of the predicted target point is imported into the GO database (http://geneontology.org/) and set threshold FDR $<0.05$. After annotating GO function, make analysis of KEGG enrichment pathway through reactome platform (https://reactome.org/Pathway Browser/), and the pathways related to HLJDD for the treatment of new coronavirus pneumonia were obtained by consulting the literature and the KEGG database. Use Omicshare (http://www.omicshare.com/tools/index.php/) to visualize the enrichment analysis results. And further carry out tissue enrichment analysis on target protein through David database (https://david.ncifcrf.gov/ ).

\section{Component-target molecular docking}

Using the PDB database[18] (https://www.rcsb.org/) to load SARS-COV-2 3CL hydrolase, ACE2 3d structure * PDB format and we predicted the structure of the TMPRSS2, and using ZINC (http://ZINC.docking.org) to collect and analyze the first five core ligands * MOL2 format. The target proteins were dewatered and hydrogenated by PyMOL software, and the compounds and the target proteins were converted to pdbqt format by Auto Dock Vina software[19]. The docking results were visualized in Pymol.

\section{Results}

\section{Collection and screening of compounds}


A total of 657 compounds were obtained from TCMSP database and related literature search. Among them, there are 143 compounds from Scutellaria baicalensis, 48 compounds from Coptis chinensis, 140 compounds from Phellodendri Chinrnsis Cortex, and 98 compounds from Gardenia jasminoides. After screening with $\mathrm{OB} \geq 30 \%$ and $\mathrm{DL} \geq 0.18$ as screening criteria, 143 compounds were obtained. After removing duplicates, there were 126 main compounds in HLJDD. They are listed in Table- 1 below. 
Ingredients of Huanglian Jiedu Decoction.

\begin{tabular}{|c|c|c|c|c|c|}
\hline Herbs & $\begin{array}{l}\text { TCMSP } \\
\text { number }\end{array}$ & Compound name & $\begin{array}{l}\text { Relative } \\
\text { molecular } \\
\text { mass }\end{array}$ & $\mathrm{OB}(\%)$ & DL \\
\hline $\begin{array}{l}\text { Scutellaria } \\
\text { baicalensis }\end{array}$ & MOL001689 & Acacetin & 284.28 & 34.97 & 0.24 \\
\hline $\begin{array}{l}\text { Scutellaria } \\
\text { baicalensis }\end{array}$ & MOL000173 & Wogonin & 284.28 & 30.68 & 0.23 \\
\hline $\begin{array}{l}\text { Scutellaria } \\
\text { baicalensis }\end{array}$ & MOL000228 & $\begin{array}{l}\text { (2R)-7-hydroxy-5-methoxy-2- } \\
\text { phenylchroman-4-one }\end{array}$ & 270.30 & 55.23 & 0.20 \\
\hline $\begin{array}{l}\text { Scutellaria } \\
\text { baicalensis }\end{array}$ & MOL002714 & Baicalein & 270.25 & 33.52 & 0.21 \\
\hline $\begin{array}{l}\text { Scutellaria } \\
\text { baicalensis }\end{array}$ & MOL002908 & 5,8,2'-Trihydroxy-7-methoxyflavone & 300.28 & 37.01 & 0.27 \\
\hline $\begin{array}{l}\text { Scutellaria } \\
\text { baicalensis }\end{array}$ & MOL002909 & 5,7,2,5-tetrahydroxy-8,6-dimethoxyflavone & 376.34 & 33.82 & 0.45 \\
\hline $\begin{array}{l}\text { Scutellaria } \\
\text { baicalensis }\end{array}$ & MOL002910 & Carthamidin & 288.27 & 41.15 & 0.24 \\
\hline $\begin{array}{l}\text { Scutellaria } \\
\text { baicalensis }\end{array}$ & MOL002911 & 2,6,2',4'-tetrahydroxy-6'-methoxychaleone & 302.30 & 69.04 & 0.22 \\
\hline $\begin{array}{l}\text { Scutellaria } \\
\text { baicalensis }\end{array}$ & MOL002913 & Dihydrobaicalin_qt & 272.27 & 40.04 & 0.21 \\
\hline $\begin{array}{l}\text { Scutellaria } \\
\text { baicalensis }\end{array}$ & MOL002914 & Eriodyctiol (flavanone) & 288.27 & 41.35 & 0.24 \\
\hline $\begin{array}{l}\text { Scutellaria } \\
\text { baicalensis }\end{array}$ & MOL002915 & Salvigenin & 328.34 & 49.07 & 0.33 \\
\hline $\begin{array}{l}\text { Scutellaria } \\
\text { baicalensis }\end{array}$ & MOL002917 & 5,2',6'-Trihydroxy-7,8-dimethoxyflavone & 330.31 & 45.05 & 0.33 \\
\hline $\begin{array}{l}\text { Scutellaria } \\
\text { baicalensis }\end{array}$ & MOL002925 & $5,7,2$ ',6'-Tetrahydroxyflavone & 286.25 & 37.01 & 0.24 \\
\hline $\begin{array}{l}\text { Scutellaria } \\
\text { baicalensis }\end{array}$ & MOL002926 & dihydrooroxylin A & 286.30 & 38.72 & 0.23 \\
\hline $\begin{array}{l}\text { Scutellaria } \\
\text { baicalensis }\end{array}$ & MOL002927 & Skullcapflavone II & 374.37 & 69.51 & 0.44 \\
\hline $\begin{array}{l}\text { Scutellaria } \\
\text { baicalensis }\end{array}$ & MOL002928 & oroxylin a & 284.28 & 41.37 & 0.23 \\
\hline $\begin{array}{l}\text { Scutellaria } \\
\text { baicalensis }\end{array}$ & MOL002932 & Panicolin & 314.31 & 76.26 & 0.29 \\
\hline $\begin{array}{l}\text { Scutellaria } \\
\text { baicalensis }\end{array}$ & MOL002933 & 5,7,4'-Trihydroxy-8-methoxyflavone & 300.28 & 36.56 & 0.27 \\
\hline Scutellaria & MOL002934 & NEOBAICALEIN & 374.37 & 104.34 & 0.44 \\
\hline
\end{tabular}


baicalensis

\begin{tabular}{lllcrr}
$\begin{array}{l}\text { Scutellaria } \\
\text { baicalensis }\end{array}$ & MOL002937 & DIHYDROOROXYLIN & 286.30 & 66.06 & 0.23 \\
$\begin{array}{l}\text { Scutellaria } \\
\text { baicalensis }\end{array}$ & MOL000358 & beta-sitosterol & 414.79 & 36.91 & 0.75 \\
$\begin{array}{l}\text { Scutellaria } \\
\text { baicalensis }\end{array}$ & MOL000359 & Sitosterol & 414.79 & 36.91 & 0.75 \\
$\begin{array}{l}\text { Scutellaria } \\
\text { baicalensis }\end{array}$ & MOL000525 & Norwogonin & 270.25 & 39.40 & 0.21 \\
\hline
\end{tabular}

$\begin{array}{llllll}\begin{array}{l}\text { Scutellaria } \\ \text { baicalensis }\end{array} & \text { MOL000552 } & 5,2 ' \text {-Dihydroxy-6,7,8-trimethoxyflavone } & 344.34 & 31.71 & 0.35\end{array}$

\begin{tabular}{lllcccc|}
$\begin{array}{l}\text { Scutellaria } \\
\text { baicalensis }\end{array}$ & MOL000073 & ent-Epicatechin & 290.29 & 48.96 & 0.24 \\
\hline $\begin{array}{l}\text { Scutellaria } \\
\text { baicalensis }\end{array}$ & MOL000449 & Stigmasterol & 412.77 & 43.83 & 0.76 \\
\hline
\end{tabular}

\begin{tabular}{|c|c|c|c|c|c|}
\hline $\begin{array}{l}\text { Scutellaria } \\
\text { baicalensis }\end{array}$ & MOL001458 & Coptisine & 320.34 & 30.67 & 0.86 \\
\hline $\begin{array}{l}\text { Scutellaria } \\
\text { baicalensis }\end{array}$ & MOL001490 & $\begin{array}{l}\text { bis[(2S)-2-ethylhexyl] benzene-1,2- } \\
\text { dicarboxylate }\end{array}$ & 390.62 & 43.59 & 0.35 \\
\hline
\end{tabular}

\begin{tabular}{llllll}
$\begin{array}{l}\text { Scutellaria } \\
\text { baicalensis }\end{array}$ & MOL001506 & Supraene & 410.80 & 33.55 & 0.42 \\
\hline
\end{tabular}

\begin{tabular}{llllll}
$\begin{array}{l}\text { Scutellaria } \\
\text { baicalensis }\end{array}$ & MOL002879 & Diop & 390.62 & 43.59 & 0.39 \\
\hline
\end{tabular}

\begin{tabular}{|lllccc|}
$\begin{array}{l}\text { Scutellaria } \\
\text { baicalensis }\end{array}$ & MOL002897 & Epiberberine & 336.39 & 43.09 & 0.78 \\
$\begin{array}{l}\text { Scutellaria } \\
\text { baicalensis }\end{array}$ & MOL008206 & Moslosooflavone & 298.31 & 44.09 & 0.25 \\
\hline
\end{tabular}

\begin{tabular}{|lccccc|}
$\begin{array}{l}\text { Scutellaria } \\
\text { baicalensis }\end{array}$ & MOL010415 & 11,13 -Eicosadienoic acid, methyl ester & 322.59 & 39.28 & 0.23 \\
$\begin{array}{l}\text { Scutellaria } \\
\text { baicalensis }\end{array}$ & MOL012245 & $5,7,4$ '-trihydroxy-6-methoxyflavanone & 302.30 & 36.63 & 0.27 \\
$\begin{array}{l}\text { Scutellaria } \\
\text { baicalensis }\end{array}$ & MOL012246 & $5,7,4$ '-trihydroxy-8-methoxyflavanone & 302.30 & 74.24 & 0.26 \\
\hline
\end{tabular}

\begin{tabular}{|lllcrr|}
\hline $\begin{array}{l}\text { Scutellaria } \\
\text { baicalensis }\end{array}$ & MOL012266 & Rivularin & 344.34 & 37.94 & 0.37 \\
\hline $\begin{array}{l}\text { Coptis } \\
\text { chinensis }\end{array}$ & MOL001454 & Berberine & 336.39 & 36.86 & 0.78 \\
\hline $\begin{array}{l}\text { Coptis } \\
\text { chinensis }\end{array}$ & MOL013352 & Obacunone & 454.56 & 43.29 & 0.77 \\
\hline $\begin{array}{l}\text { Coptis } \\
\text { chinensis }\end{array}$ & MOL002894 & berberrubine & 322.36 & 35.74 & 0.73 \\
\hline
\end{tabular}




\begin{tabular}{|c|c|c|c|c|c|}
\hline $\begin{array}{l}\text { Coptis } \\
\text { chinensis }\end{array}$ & MOL002897 & epiberberine & 336.39 & 43.09 & 0.78 \\
\hline $\begin{array}{l}\text { Coptis } \\
\text { chinensis }\end{array}$ & MOL002903 & (R)-Canadine & 339.42 & 55.37 & 0.77 \\
\hline $\begin{array}{l}\text { Coptis } \\
\text { chinensis }\end{array}$ & MOL002904 & Berlambine & 351.38 & 36.68 & 0.82 \\
\hline $\begin{array}{l}\text { Coptis } \\
\text { chinensis }\end{array}$ & MOL002907 & Corchoroside A_qt & 404.55 & 104.95 & 0.78 \\
\hline $\begin{array}{l}\text { Coptis } \\
\text { chinensis }\end{array}$ & MOL000622 & Magnograndiolide & 266.37 & 63.71 & 0.19 \\
\hline $\begin{array}{l}\text { Coptis } \\
\text { chinensis }\end{array}$ & MOL000762 & Palmidin A & 510.52 & 35.36 & 0.65 \\
\hline $\begin{array}{l}\text { Coptis } \\
\text { chinensis }\end{array}$ & MOL000785 & palmatine & 352.44 & 64.60 & 0.65 \\
\hline $\begin{array}{l}\text { Coptis } \\
\text { chinensis }\end{array}$ & MOL000098 & quercetin & 302.25 & 46.43 & 0.28 \\
\hline $\begin{array}{l}\text { Coptis } \\
\text { chinensis }\end{array}$ & MOL001458 & coptisine & 320.34 & 30.67 & 0.86 \\
\hline $\begin{array}{l}\text { Coptis } \\
\text { chinensis }\end{array}$ & MOL002668 & Worenine & 334.37 & 45.83 & 0.87 \\
\hline $\begin{array}{l}\text { Coptis } \\
\text { chinensis }\end{array}$ & MOL008647 & Moupinamide & 313.38 & 86.71 & 0.26 \\
\hline $\begin{array}{l}\text { Phellodendri } \\
\text { Chinrnsis } \\
\text { Cortex }\end{array}$ & MOL001454 & berberine & 336.39 & 36.86 & 0.78 \\
\hline $\begin{array}{l}\text { Phellodendri } \\
\text { Chinrnsis } \\
\text { Cortex }\end{array}$ & MOL001458 & coptisine & 320.34 & 30.67 & 0.86 \\
\hline $\begin{array}{l}\text { Phellodendri } \\
\text { Chinrnsis } \\
\text { Cortex }\end{array}$ & MOL002636 & Kihadalactone A & 512.70 & 34.21 & 0.82 \\
\hline $\begin{array}{l}\text { Phellodendri } \\
\text { Chinrnsis } \\
\text { Cortex }\end{array}$ & MOL013352 & Obacunone & 454.56 & 43.29 & 0.77 \\
\hline $\begin{array}{l}\text { Phellodendri } \\
\text { Chinrnsis } \\
\text { Cortex }\end{array}$ & MOL002641 & Phellavin_qt & 374.42 & 35.86 & 0.44 \\
\hline $\begin{array}{l}\text { Phellodendri } \\
\text { Chinrnsis } \\
\text { Cortex }\end{array}$ & MOL002643 & delta 7-stigmastenol & 414.79 & 37.42 & 0.75 \\
\hline $\begin{array}{l}\text { Phellodendri } \\
\text { Chinrnsis } \\
\text { Cortex }\end{array}$ & MOL002644 & Phellopterin & 300.33 & 40.19 & 0.28 \\
\hline
\end{tabular}




\section{Phellodendri MOL002651 Dehydrotanshinone II A \\ Chinrnsis \\ Cortex}

Phellodendri MOL002652 delta7-Dehydrosophoramine

Chinrnsis

$292.35 \quad 43.76$

0.40

Cortex

Phellodendri MOL002656 dihydroniloticin
Chinrnsis
Cortex

Phellodendri MOL002659 kihadanin A

\section{Chinrnsis}

242.35

54.45

0.25

Cortex

\section{Phellodendri MOL002660 Niloticin \\ Chinrnsis \\ Cortex}
Phellodendri MOL002662 rutaecarpine
Chinrnsis
Cortex

Phellodendri MOL002663 Skimmianin
Chinrnsis
Cortex

Phellodendri MOL002666 Chelerythrine

\section{Chinrnsis}

Cortex

\section{Phellodendri MOL000449 Stigmasterol \\ Chinrnsis \\ Cortex}
Phellodendri MOL002668 Worenine
Chinrnsis
Cortex
Phellodendri MOL002670 Cavidine
Chinrnsis
Cortex
Phellodendri MOL002671 Candletoxin A
Chinrnsis
Cortex

\begin{tabular}{|llllll|}
$\begin{array}{l}\text { Phellodendri } \\
\text { Chinnsis } \\
\text { Cortex }\end{array}$ & MOL002672 & Hericenone H & 580.88 & 39.00 & 0.63 \\
\hline $\begin{array}{l}\text { Phellodendri } \\
\text { Chinrnsis } \\
\text { Cortex }\end{array}$ & MOL002673 & Hispidone & 472.78 & 36.18 & 0.83 \\
\hline $\begin{array}{l}\text { Phellodendri } \\
\text { Chinrnsis } \\
\text { Cortex }\end{array}$ & MOL000358 & beta-sitosterol & 414.79 & 36.91 & 0.75 \\
\hline $\begin{array}{l}\text { Phellodendri } \\
\text { Chinrnsis }\end{array}$ & MOL000622 & Magnograndiolide & & & \\
\hline
\end{tabular}




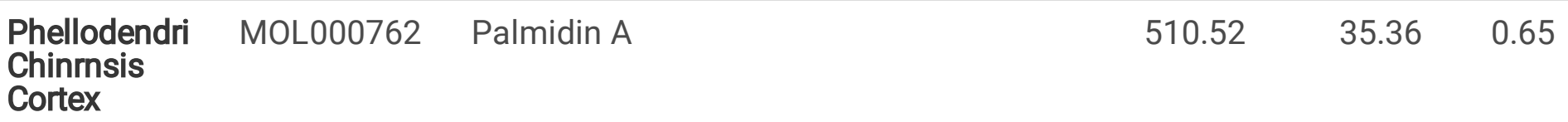

Phellodendri MOL000785 palmatine

352.44

64.60

0.65

Chinrnsis

Cortex

Phellodendri MOL000787 Fumarine

353.40

59.26

0.83

Chinrnsis

Cortex

Phellodendri MOL000790 Isocorypalmine

Chinrnsis

$\begin{array}{lll}341.44 & 35.77 & 0.59\end{array}$

Cortex

Phellodendri MOL000098 quercetin

Chinrnsis

Cortex

$\begin{aligned} & \text { Phellodendri } \\ & \text { Chinrnsis }\end{aligned}$
Cortex

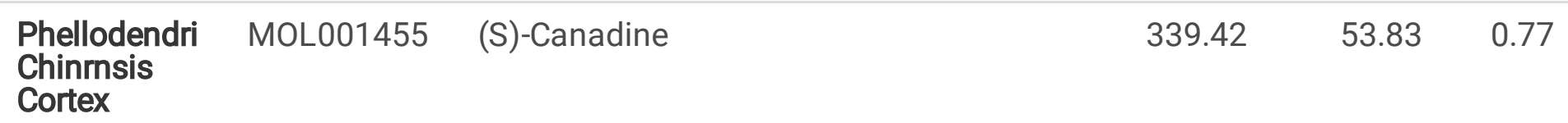

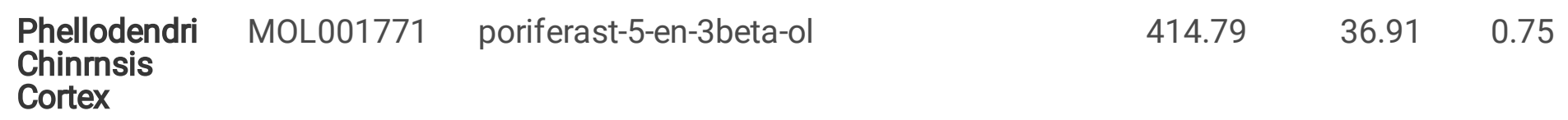

$\begin{array}{llllll}\text { Phellodendri } & \text { MOL002894 } & \text { berberrubine } & 322.36 & 35.74 & 0.73\end{array}$

Chinrnsis

Cortex

$\begin{array}{llllll}\text { Phellodendri } & \text { MOL005438 } & \text { campesterol } & 400.76 & 37.58 & 0.71 \\ \text { Chinrnsis } & \text { Cortex } & & & & \end{array}$

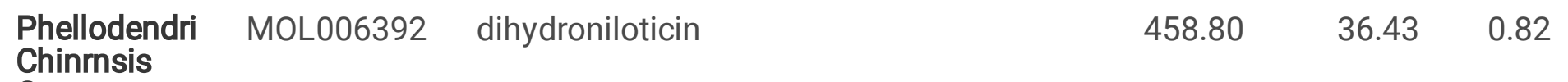

Cortex

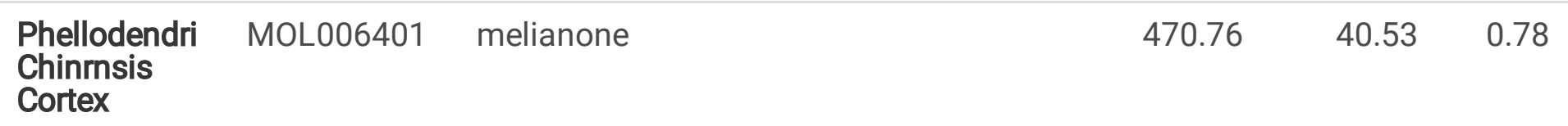

$\begin{array}{llllll}\text { Phellodendri } & \text { MOL006413 } & \text { phellochin } & 488.83 & 35.41 & 0.82\end{array}$

Chinrnsis

Cortex

\begin{tabular}{|c|c|c|}
\hline $\begin{array}{l}\text { Phellodendri } \\
\text { Chinmssis }\end{array}$ & MOL006422 & thalifendine \\
\hline
\end{tabular}

Cortex

$\begin{array}{llllll}\text { Gardenia } & \text { MOL001663 } & (4 a S, 6 a R, 6 a S, 6 b R, 8 a R, 10 R, 12 a R, 14 b S)-10- & 456.78 & 32.03 & 0.76 \\ \text { jasminoides } & \text { hydroxy-2,2,6a,6b,9,9,12a-heptamethyl- } & & & \\ & 1,3,4,5,6,6 \mathrm{a}, 7,8,8 \mathrm{a}, 10,11,12,13,14 \mathrm{~b}- \\ & \text { tetradecahydropicene-4a-carboxylic acid } & & \end{array}$




\begin{tabular}{|c|c|c|c|c|c|}
\hline $\begin{array}{l}\text { Gardenia } \\
\text { jasminoides }\end{array}$ & MOL002883 & Ethyl oleate (NF) & 310.58 & 32.40 & 0.19 \\
\hline $\begin{array}{l}\text { Gardenia } \\
\text { jasminoides }\end{array}$ & MOL001506 & Supraene & 410.80 & 33.55 & 0.42 \\
\hline $\begin{array}{l}\text { Gardenia } \\
\text { jasminoides }\end{array}$ & MOL001941 & Ammidin & 270.30 & 34.55 & 0.22 \\
\hline $\begin{array}{l}\text { Gardenia } \\
\text { jasminoides }\end{array}$ & MOL001406 & Crocetin & 328.44 & 35.30 & 0.26 \\
\hline $\begin{array}{l}\text { Gardenia } \\
\text { jasminoides }\end{array}$ & MOL000358 & beta-sitosterol & 414.79 & 36.91 & 0.75 \\
\hline $\begin{array}{l}\text { Gardenia } \\
\text { jasminoides }\end{array}$ & MOL000422 & kaempferol & 286.25 & 41.88 & 0.24 \\
\hline $\begin{array}{l}\text { Gardenia } \\
\text { jasminoides }\end{array}$ & MOL001494 & Mandenol & 308.56 & 42.00 & 0.19 \\
\hline $\begin{array}{l}\text { Gardenia } \\
\text { jasminoides }\end{array}$ & MOL000449 & Stigmasterol & 412.77 & 43.83 & 0.76 \\
\hline $\begin{array}{l}\text { Gardenia } \\
\text { jasminoides }\end{array}$ & MOL001942 & isoimperatorin & 270.30 & 45.46 & 0.23 \\
\hline $\begin{array}{l}\text { Gardenia } \\
\text { jasminoides }\end{array}$ & MOL009038 & GBGB & 550.57 & 45.58 & 0.83 \\
\hline $\begin{array}{l}\text { Gardenia } \\
\text { jasminoides }\end{array}$ & MOL000098 & quercetin & 302.25 & 46.43 & 0.28 \\
\hline $\begin{array}{l}\text { Gardenia } \\
\text { jasminoides }\end{array}$ & MOL003095 & $\begin{array}{l}\text { 5-hydroxy-7-methoxy-2-(3,4,5- } \\
\text { trimethoxyphenyl)chromone }\end{array}$ & 358.37 & 51.96 & 0.41 \\
\hline $\begin{array}{l}\text { Gardenia } \\
\text { jasminoides }\end{array}$ & MOL007245 & 3-Methylkempferol & 300.28 & 60.16 & 0.26 \\
\hline $\begin{array}{l}\text { Gardenia } \\
\text { jasminoides }\end{array}$ & MOL004561 & Sudan III & 352.42 & 84.07 & 0.59 \\
\hline
\end{tabular}

\section{Component-target network of HLJDD}

The corresponding targets of the main compounds of HLJDD were collected in the TCMSP database, and the results were imported into Cytoscape 3.7.2. The active ingredient-prediction target network was constructed, and 425 nodes (84 active ingredient nodes and 341 predicted target nodes) and 1801 interaction relationships were obtained, as shown in Figure 2. Among them, yellow represents the compound of Scutellaria baicalensis, green represents the compound of Coptis chinensis, red represents the compound of Phellodendron amurense, and blue represents the compound of Gardenia jasminoides. 


\section{Intersecting compounds in HLJDD}

From the result of "3.2", it can be known that the same compound exists in different medicinal materials in HLJDD. It can be obtained from Funrich's Venn diagram (Figure 3). Coptis chinensis and Phellodendron amurense all have MOL001454-Berberine and MOL002894- Berberrubine; MOL000358-Beta-sitosterol is common to Scutellaria baicalensis, Phellodendron amurense and Gardenia jasminoides; MOL001458Coptisine is common to Coptis chinensis, Scutellaria baicalensis and Phellodendron amurense; MOL002897Epiberberine is common to Coptis chinensis and Scutellaria baicalensis;MOL000622-Magnograndiolide, MOL013352-Obacunone, MOL000785-Palmatine, MOL000762-Palmidin-A is common to Coptis chinensis and Phellodendron amurense; MOL000098-Quercetin is common to Coptis chinensis, Phellodendron amurense and Gardenia jasminoides; Scutellaria baicalensis, Phellodendron amurense and Gardenia jasminoides all have MOL000449-Stigmasterol; Scutellaria baicalensis and Gardenia jasminoides both have MOL001506-Supraene; Coptis chinensis and Phellodendron amurense both have MOL002668-Worenine.

\section{GO, KEGG and Tissue enrichment analysis}

The GO database was used to annotate the GO functional annotation of HLJDD and the Pathway analysis of reactome. GO function annotation is to annotate and classify genes through biological processes (BP), cell components (CC), and molecular function (MF), as shown in Figure 4. For each biological process, cellular components and molecular functional categories are represented by red, blue, and green bars, respectively. The height of the bar graph represents the number of genes in which the annotated genes overlap. Biological regulation, stress response, and metabolic processes are highly relevant in biological processes, mainly including nitrogen utilization regulation, cell response to vitamin $\mathrm{E}$, negative regulation of chronic inflammatory responses, regulation of fibroblast differentiation, and smooth muscle cell-matrix adhesion regulation, inflammatory apoptotic process and blood pressure regulation, etc. The proportion of cell membrane, nucleus, and cytoplasmic matrix in the cell components is relatively high, and protein binding, ion binding, and molecular sensor activity have a great impact on molecular functions.

KEGG pathway enrichment screen obtained 306 signal pathways $(P<0.05)$, as shown in Figures 5 and 6 , including nuclear receptor transcription pathway, SREBF (SREBP) activation gene expression, SREBP (SREBF) regulation of cholesterol biosynthesis, interleukin 4 And interleukin 13 signaling, RNA polymerase II transcription, universal transcription pathway, cytokine signaling in the immune system, interleukin signaling, gene expression (transcription), nuclear receptor signaling, extranuclear estrogen signaling, ESR-mediated signaling Conduction, cell senescence, estrogen-dependent nuclear events downstream of ESR membrane signals, interleukin 10 signals, intrinsic pathways of apoptosis, steroid metabolism, immune system, amine ligand binding receptors and VEGF signal transduction, etc. The immune system involved 175 related genes such as IL6, NOS2, IL10, TGFB1, AKT1, IL2, IL4, FOS, CCL2, CASP3, CXCL8, CXCL2, SOD1, ALOX5, STAT1, CXCL10, MYC, MAPK10 and MAPK14.

Further carry out tissue enrichment analysis on targets. As shown in Figure 7, tissue enrichment revealed that targets expression sites are mainly distributed in lung tissue, liver, and placenta, and involve a variety of 
immune cells, such as T cells and B cells. It shows that the key targets of the active ingredients of HLJDD are mainly expressed in lung tissues and immune cells.

\section{Component-target molecular docking}

It is generally believed that the lower the energy is, the more stable conformation of the ligand-receptor binding is, the more likely the interaction is. The results of molecular docking showed that the affinity of the core active compounds in HLJDD to SARS-COV-2 3CL hydrolase, ACE2 and TMPRSS2 was less than zero, which indicated that the core active compounds in HLJDD could spontaneously bind to SARS-COV-2 3CL hydrolase, ACE2, TMPRSS2. The results are shown in table 2.The result of molecular docking showed that the binding energy of ACE2 with stigmasterol was $-9.1 \mathrm{KJ} / \mathrm{Mol}$.And the binding energy of SARS-COV-2 3CL hydrolase and TMPRSS2 with beta sitosterol was $-7.5 \mathrm{KJ} / \mathrm{Mol}$ and $8.4 \mathrm{KJ} / \mathrm{Mol}$ respectively. The results show that the conformation of the Ligand and its receptor is the most stable. The binding ability of the major components in HLJDD to the SARS-COV-2 3CL hydrolase, ACE2, TMPRSS2 is lower than that of the effective drugs reported so far, which indicates that the major components in HLJDD bind to the SARS-COV-2 3CL hydrolase, ACE2, TMPRSS2 more stable and have more possibility to play a role. The docking results are shown in Figure 8-1,2,3.

Table 2

The binding energy values of the core compounds and SARS-CoV-2 3CL hydrolase in HLJDD and effective drugs reported clinically

\begin{tabular}{|lllll|}
\hline Receptor & ligand & Formula & MW(g/mol) & $\begin{array}{c}\text { binding energy } \\
\text { VkJ/mol }\end{array}$ \\
\hline $\begin{array}{l}\text { SARS-CoV-2 3CL } \\
\text { hydrolase }\end{array}$ & Stigmasterol & C29H480 & 412.70 & -4.13 \\
\hline $\begin{array}{l}\text { SARS-CoV-2 3CL } \\
\text { hydrolase }\end{array}$ & beta_sitosterol & C29H500 & 414.70 & -3.85 \\
\hline $\begin{array}{l}\text { SARS-CoV-2 3CL } \\
\text { hydrolase }\end{array}$ & abidol & C30H4006 & 496.60 & -3.14 \\
\hline $\begin{array}{l}\text { SARS-CoV-2 3CL } \\
\text { hydrolase }\end{array}$ & kaempferol & C15H1006 & 286.24 & -3.11 \\
\hline $\begin{array}{l}\text { SARS-CoV-2 3CL } \\
\text { hydrolase }\end{array}$ & quercetin & C15H1007 & 302.23 & -3.08 \\
\hline $\begin{array}{l}\text { SARS-CoV-2 3CL } \\
\text { hydrolase }\end{array}$ & lopinavir & C37H48N405 & 628.80 & -1.53 \\
\hline $\begin{array}{l}\text { SARS-CoV-2 3CL } \\
\text { hydrolase }\end{array}$ & daruinavir & C27H37N307S & 547.66 & -1.39 \\
\hline $\begin{array}{l}\text { SARS-CoV-2 3CL } \\
\text { hydrolase }\end{array}$ & supraene & C30H50 & 410.72 & -0.85 \\
\hline $\begin{array}{l}\text { SARS-CoV-2 3CL } \\
\text { hydrolase }\end{array}$ & ritonavir & C37H48N605S2 & 720.94 & 0.05 \\
\hline
\end{tabular}




\section{Discussion}

The serious situation of the new coronavirus pneumonia brings a heavy economic burden to the country by the long treatment cycle and high consumption of materials. So finding effective ways to curb the development of new pneumonia is urgent. From the end of December 2019 to the present, there is still no specific medicine for the treatment of COVID-19, and the existing chemical medicines can only alleviate some symptoms. Although recent research reports that Remdesivir has a significant effect, the drug is still in the research and development stage due to the small sample size and cannot be used in the clinic for a short time[20]. Since ancient times, traditional Chinese medicine has played a very good role in treating complex diseases and new diseases. From the outbreak of the epidemic situation, traditional Chinese medicine has also had relatively obvious curative effects in this new coronary pneumonia. This prescription is mainly used for the treatment of patients with moderate to severe illness. Therefore, studying the active ingredients, therapeutic targets and molecular docking mechanisms of this prescription can provide a theoretical basis for the treatment of a large number of patients with moderate and severe illness. Interventional treatment in the middle and severe stages of the disease, preventing the development of the critically ill patients in the critical direction, greatly saving medical resources, reducing the burden on the country, society and individuals, is of great significance to ending the epidemic as soon as possible.

In this study, after analyzing the active ingredients through the network pharmacology method, 341 potential targets, 307 biological processes, 107 molecular functions, and 306 KEGG pathways were obtained. After preliminary clinical observation, the common clinical symptoms of the new coronavirus infection are dyspnea, and severely ill patients will have a significant increase in proinflammatory cytokines such as IL-6, TNF-a, IFN- $\gamma$, which has the characteristics of cytokine storm [21]. Studies have found that serum matrix metalloproteinase 9 (MMP9) and transforming growth factor beta (TGF- $\beta$ ) are common airway remodeling related proteins $[22,23]$. They can mediate the inflammatory response and damage the airway. In severe cases, the airflow is restricted, and the restricted airflow can lead to a lack of effective ventilation. The main manifestations in clinical symptoms are dyspnea and decreased lung function[24, 25]. We speculate that Huanglian Jiedu Decoction may inhibit airway remodeling and improve dyspnea by inhibiting the expression of MMP9 and TGF- $\beta$. The cytokine storm, also known as the "inflammatory storm", is actually an important node in the transition from mild patients to critically ill patients, and it is also a cause of death of severe patients now[26-29]. Once an inflammatory storm is formed, while the immune system kills the virus, it will also kill a large number of normal cells in the lung, severely destroying the lung's ventilation function, leading to respiratory failure until hypoxia and death. It has also been found in recent years that the alveolar inflammatory response caused by the release of inflammatory cytokines is the main cause of lung injury[28]. IL6 is a pro-inflammatory factor, and its main function is to accelerate the alveolar inflammation in the early stage of pulmonary fibrosis through chemotactic inflammatory cell aggregation and promote inflammatory cell infiltration, and then mediate the occurrence of idiopathic pulmonary fibrosis[27, 30]. IL10 is a class of anti-inflammatory factors that play an important role in the occurrence of various organ fibrotic diseases. At the same time, it has immunomodulatory effects such as inhibiting monocytes / macrophages, Th1 cell functions, and enhancing B cell functions[31, 32]. And the latest research found that interleukin-6 (IL-6) is an important inflammatory factor that induces the inflammatory storm of neocorona virus pneumonia[33, 34]. Based on the preliminary understanding of the mechanism and the KEGG analysis results, it is speculated

Page 14/ 27 
that the core active compounds in HLJDD may regulate cytokine signaling and interleukin signaling in the immune system by acting on genes such as IL6 and IL10 (show as Fig. 9). From the perspective of immune regulation and suppression of inflammation, inhibit excessive immune cell activation and cytokine production to block the occurrence of inflammatory storms; Pulmonary microangiogenesis is also an important part of pulmonary fibrosis. VEGF is an important factor that promotes angiogenesis. It mainly exerts its physiological function by binding with receptors (VEGFR1, VEGFR2, etc.)[35]. Under pathological conditions, their combination can inhibit the apoptosis of vascular endothelial cells, promote their proliferation, migration and differentiation, increase vascular permeability, and stimulate neovascularization in the body[36]. Moreover, some studies have found that NO / NOS (nitrogen oxide synthase) pathway may be involved in its role in promoting angiogenesis[37]. Therefore, it is speculated that Huanglian Jiedu Decoction may inhibit VEGF signal transduction by acting on VEGFA, NOS2, NOS3 and other genes, reduce pulmonary fibrosis, and play a role in treating COVID-19.

The results of molecular docking showed that the conformations of ACE2 hydrolase and Stigmasterol was the most stable and the possibility of their action was the greatest. This indicates that Stigmasterol in Scutellaria baicalensis and Phellodendron amurense plays a more important role in the treatment of new coronary pneumonia. Studies have shown that Stigmasterol has potent anti-tumor, anti-inflammatory and anti-oxidative effects[38, 39]. SARS-CoV-2 3CL hydrolase and TMPRSS2 also showed good binding activity to beta sitosterol, which was mainly derived from Scutellaria baicalensis, Phellodendron amurense and Gardenia jasminoides. Some studies have shown that beta sitosterol has certain anti-inflammatory effects[40, 41], and can be combined with PLY cholesterol binding site to prevent the toxin from binding to membrane, playing a competitive antagonistic role, thus to have an anti-infective effect[42]. Therefore, it is speculated that HLJDD may play a better role in the treatment of COVID-19 through its competitive antagonism, anti-inflammation and anti-oxidation.

\section{Conclusion}

Overall, this study applied network pharmacology and molecular docking methods to explore the chemical constituents, action targets and its core active compounds in HLJDD, as well as the binding energy with SARS-CoV-2 3CL hydrolase, ACE2 and TMPRSS2. The active compounds such as stigmasterol, betasitosterol, and quercetin in Huanglian Jiedu Decoction may have a therapeutic effect on COVID-19 through regulating multiple signal pathways by targeting genes such as VEGF, NOS2, IL6, MMP9, IL10, and TGFB1. However, since this study is mainly discussed at the theoretical level, further experimental research on pharmacodynamic evaluation, metabolomics, and clinical efficacy is needed to provide a solid basis for the treatment of COVID-19 and drug development in the later stage.

\section{Abbreviations}

HLJDD: Huanglian Jiedu Decoction;

COVID-19: Corona Virus Disease 2019;

ACE 2: Angiotensin-Converting Enzyme 2; 
TMPRSS2: Transmembrane Protease Serine 2;

KEGG: Kyoto Encyclopedia of Genes and Genomes;

TCMSP: Traditional Chinese Medicine Systems Pharmacology;

OB: Oral bioavailability;

DL: Drug-likeness;

BP: Biological processes;

CC: cell components;

MF: molecular function;

IL-6: interleukin-6;

TGF- $\beta$ : transforming growth factor beta;

MMP9: matrix metalloproteinase 9

\section{Declarations}

\section{Availability of data and materials}

Not appliacable

\section{Funding}

This work was supported by National Natural Science Foundation of China (No. 81573091 and No. 81802668) and Natural Science Foundation of Hunan Province (No. 2018JJ3776 and No. 2017JJ3467).

\section{Acknowledgements}

We appreciate the doctors, nurses and scientists who are making efforts to against the COVID-19 epidemic around the world. Thank you everyone for your contribution.

\section{Contributions}

LP and $X Y$ designed and performed the study. LP, XY, XS and QL wrote the manuscript with inputs from all authors. YW and RG performed the analytic calculations and statistical analysis. All authors provided critical feedback and helped to shape the research, analysis, and manuscript. 


\section{Ethics declatations}

\section{Ethics approval and consent to participate}

Not applicable.

\section{Consent for publication}

We declare that the Publisher has the Author's permission to publish the relevant contribution.

\section{Competing interests}

The authors have no conflicts of interest to declare.

\section{References}

1. Shu-min L, Jun-hang L, Chang-feng $L$, et al. [Effects of Chinese herbal medicine Huanglian Jiedu Decoction on urine metabonomics of healthy people]. Zhong xi yi jie he xue bao = Journal of Chinese integrative medicine 2011;9.

2. Shibo J, Du Lanying, Zhengli S. An emerging coronavirus causing pneumonia outbreak in Wuhan, China: calling for developing therapeutic and prophylactic strategies. EMERG MICROBES INFEC 2020;9.

3. Fuk-Woo CJ, Kin-Hang K, Zheng Z, et al. Genomic characterization of the 2019 novel human-pathogenic coronavirus isolated from a patient with atypical pneumonia after visiting Wuhan. EMERG MICROBES INFEC 2020;9.

4. Ruiyin W, Jiangtao L. Analysis of the Mechanism of Zhichuanling Oral Liquid in Treating Bronchial Asthma Based on Network Pharmacology. Evidence-based complementary and alternative medicine : eCAM 2020;2020.

5. Y O, T K, K N, et al. Preventive effect of Oren-gedoku-to (Huanglian-Jie-Du-Tang) extract on the development of stress-induced acute gastric mucosal lesions in rats. J ETHNOPHARMACOL 2000;67.

6. M WL, S M. Preventive effects of unsei-in and oren-gedoku-to, Chinese traditional medicines, against rat paw oedema and abdominal constriction in mice. The Journal of pharmacy and pharmacology 1996;48.

7. Hu Y, Jiang P, Wang S, Yan S, et al. Plasma pharmacochemistry based approach to screening potential bioactive components in Huang-Lian-Jie-Du-Tang using high performance liquid chromatography coupled with mass spectrometric detection. J ETHNOPHARMACOL 2012;141.

8. Lu J, Wang J, Kong L. Anti-inflammatory effects of Huang-Lian-Jie-Du decoction, its two fractions and four typical compounds.;134:918.

9. Zeng H, Dou S, Zhao J, et al. The inhibitory activities of the components of Huang-Lian-Jie-Du-Tang (HLJDT) on eicosanoid generation via lipoxygenase pathway. J ETHNOPHARMACOL 2011;135. 
10. Choi WM, Lam CL, Mo WY, et al. Effects of the modified Huanglian Jiedu decoction on the disease resistance in grey mullet (Mugil cephalus ) to Lactococcus garvieae. MAR POLLUT BULL 2014;85.

11. Li J, Lu C, Jiang M, et al. Traditional Chinese Medicine-Based Network Pharmacology Could Lead to New Multicompound Drug Discovery. 2012;2012:149762.

12. LI S, ZHANG B. Traditional Chinese medicine network pharmacology: theory, methodology and application. CHIN J NAT MEDICINES 2013;11.

13. Knegtel RMA, Kuntz ID, Oshiro CM. Molecular docking to ensembles of protein structures 11 Edited by B. Honig. J MOL BIOL 1996;266.

14. Shao-Jie H, Fei M, Fei L, et al. Systematic Elucidation of the Potential Mechanism of Erzhi Pill against Drug-Induced Liver Injury via Network Pharmacology Approach. Evidence-based complementary and alternative medicine : eCAM 2020;2020.

15. Tao W, Xu X, Wang X, Li B, et al. Network pharmacology-based prediction of the active ingredients and potential targets of Chinese herbal Radix Curcumae formula for application to cardiovascular disease. $J$ ETHNOPHARMACOL 2013;145.

16. Du X, Zhao L, Yang Y, Zhang Z, et al. Investigation of the mechanism of action of Porana sinensis Hemsl. against gout arthritis using network pharmacology and experimental validation. J ETHNOPHARMACOL 2020;252.

17. Yunbin J, Mei Z, Fei L, et al. Deciphering the Active Ingredients and Molecular Mechanisms of Tripterygium hypoglaucum (Levl.) Hutch against Rheumatoid Arthritis Based on Network Pharmacology. Evidence-based complementary and alternative medicine : eCAM 2020;2020.

18. K BS, M BH, J KG,et al. Protein Data Bank (PDB): The Single Global Macromolecular Structure Archive. Methods in molecular biology (Clifton, N.J.) 2017;1607.

19. Oleg T, J OA. AutoDock Vina: improving the speed and accuracy of docking with a new scoring function, efficient optimization, and multithreading. J COMPUT CHEM 2010;31.

20. L HM, Chas D, Scott L, et al. First Case of 2019 Novel Coronavirus in the United States. The New England journal of medicine 2020.

21. Seifart C, Dempfle A, Plagens A, et al. TNF-alpha-, TNF-beta-, IL-6-, and IL-10-promoter polymorphisms in patients with chronic obstructive pulmonary disease. 2005;65:93-100.

22. Ugarteberzal E. VEGF/VEGFR2 interaction down-regulates matrix metalloproteinase-9 via STAT1 activation and inhibits B chronic lymphocytic leukemia cell migration. 2010;115:846.

23. Baarsma HA, R. SAI, Gertruud H, et al. Activation of WNT / $\beta$-Catenin Signaling in Pulmonary Fibroblasts by TGF- $\beta 1$ Is Increased in Chronic Obstructive Pulmonary Disease. PLOS ONE;6:e25450.

24. Alfonso F, Floriana M, Morena F, et al. The value of matrix metalloproteinase- 9 and vascular endothelial growth factor receptor 1 pathway in diagnosing indeterminate pleural effusiont. Interactive Cardiovascular \& Thoracic Surgery 2012:3.

25. Abdul Muneer PM, Alikunju S, Szlachetka AM, et al. The Mechanisms of Cerebral Vascular Dysfunction and Neuroinflammation by MMP-Mediated Degradation of VEGFR-2 in Alcohol Ingestion. Arteriosclerosis Thrombosis \& Vascular Biology 2012. 
26. Huang KJ, Su IJ, Theron M, et al. An interferon-?-related cytokine storm in SARS patients. J MED VIROL 2005;75:185-194.

27. Lijun LI, Fan A, Dongyu GE, et al. Astragalus Angelica Ratio of Drug Doses and on IPF Mice Survival Condition and TGF-beta,IL-6,Foxp3,ROR Gamma t the Influence of the Level of Gene Expression. Journal of Liaoning University of Traditional Chinese Medicine 2015.

28. Toshio T, Masashi N, Tadamitsu K. Immunotherapeutic implications of IL-6 blockade for cytokine storm. IMMUNOTHERAPY-UK 2016;8.

29. Lei Z, Yunhui L. Potential Interventions for Novel Coronavirus in China: A Systemic Review. J MED VIROL 2020.

30. Bao WH, Da-Peng HU, Yang XD, et al. Expression and clinical significance of serum IL-9,IL-10 and PU. 1 in patients with idiopathic pulmonary fibrosis. Journal of Clinical Pulmonary Medicine 2016.

31. Carine S, C BC. Fine Tuning the Cytokine Storm by IFN and IL-10 Following Neurotropic Coronavirus Encephalomyelitis. FRONT IMMUNOL 2018;9.

32. Ming-Hsien T, Chung-Hsing C, Rong-Kung T, et al. Cross-Regulation of Proinflammatory Cytokines by Interleukin-10 and miR-155 in Orientia tsutsugamushi-Infected Human Macrophages Prevents Cytokine Storm. The Journal of investigative dermatology 2016;136.

33. Huang C, Wang Y, Li X, et al. Clinical features of patients infected with 2019 novel coronavirus in Wuhan, China. The Lancet 2020;395.

34. Ma Q, Huang W, Zhao J, et al. Liu Shen Wan inhibits influenza a virus and excessive virus-induced inflammatory response via suppression of TLR4/NF-KB signaling pathway in vitro and in vivo. $J$ ETHNOPHARMACOL 2020;252.

35. Farkas L, Farkas D, Ask K, et al. VEGF ameliorates pulmonary hypertension through inhibition of endothelial apoptosis in experimental lung fibrosis in rats. J CLIN INVEST 2009;119.

36. Takahashi $H$, Shibuya M. The vascular endothelial growth factor (VEGF)/VEGF receptor system and its role under physiological and pathological conditions. CLIN SCl,109:227.

37. Mauo-Ying B, Ming-Ping W, Wei-Lin C, et al. VEGF correlates with inflammation and fibrosis in tuberculous pleural effusion. TheScientificWorldJournal 2015;2015.

38. Zhou ZY, Qun LU, Liu Y, Xie Z, et al, University GP. Research and development progress of stigmasterol. China Modern Medicine 2015.

39. Hernández-Valle E, Herrera-Ruiz M, Salgado G, et al. Anti-Inflammatory Effect of 3-0-[(6\"-O-Palmitoyl)- $\beta$ D-glucopyranosyl Sitosterol] from Agave angustifolia on Ear Edema in Mice. MOLECULES,19:1562415637.

40. Uddin G, Rauf A, Siddiqui BS, et al Anti-nociceptive, anti-inflammatory and sedative activities of the extracts and chemical constituents of Diospyros lotus L. PHYTOMEDICINE 2014;21.

41. Han NR, Kim HM, Jeong HJ. The ?-sitosterol attenuates atopic dermatitis-like skin lesions through downregulation of TSLP. Experimental Biology \& Medicine,239:454-464.

42. Choi JN, Choi Y, Lee J, et al. Anti-inflammatory effects of $\beta$-sitosterol- $\beta-\backslash r<s c p>D</$ scp $>\backslash r$-glucoside from $\backslash r$ Trachelospermum jasminoides $\backslash r$ (Apocynaceae) in lipopolysaccharide-stimulated RAW 264.7 murine macrophages. NAT PROD RES,26:2340-2343. 


\section{Figures}

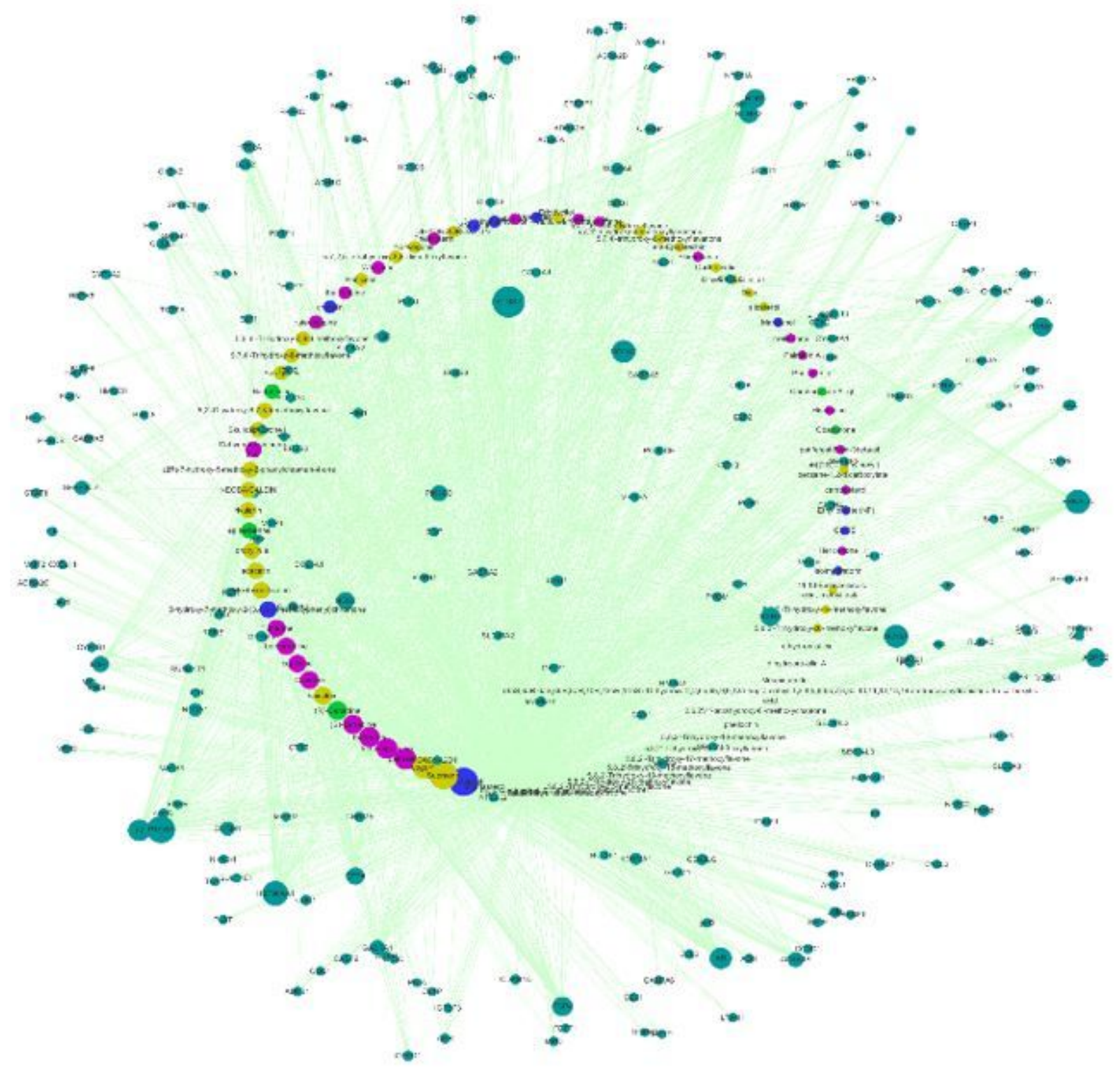

\section{Figure 1}

The target network diagram of the compound of Huanglian Jiedu Decoction. Inputting the active ingredients and targets of HLJDD from TCSMP into Cytoscape 3.7.2 software and producting the network upside. Among the network figure, yellow represents the compound of Scutellaria baicalensis, green represents the compound of Coptis chinensis, red represents the compound of Phellodendron amurense, and blue represents the compound of Gardenia jasminoides; the nodes` size represents the degree, the edges between the nodes represents the interrelations of the active compounds and targets. 


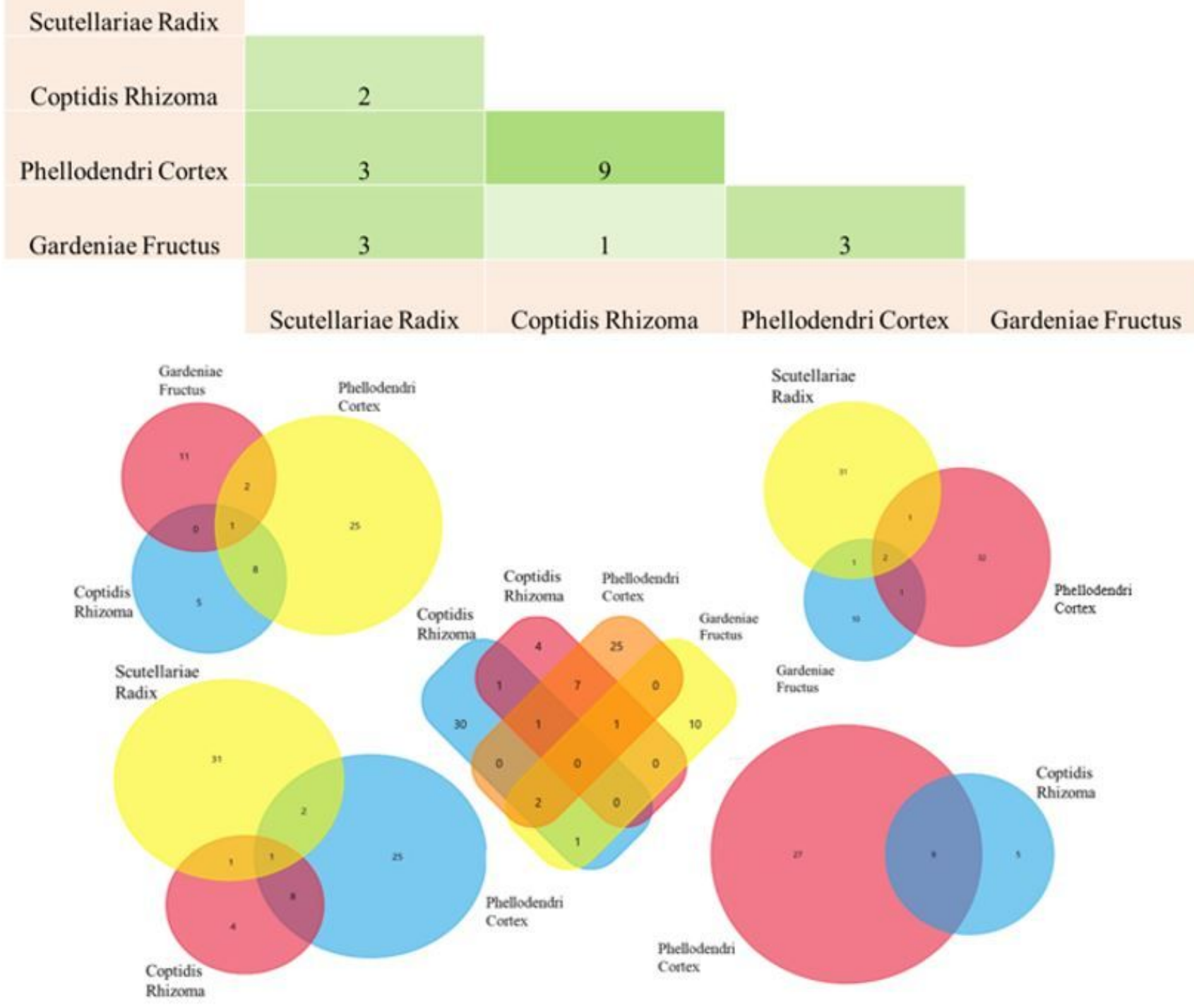

\section{Figure 2}

Distribution of compounds in Huanglian Jiedu Decoction The active compound information of HLJDD was input into Funrich to make a Venn diagram, and the same compound was found in different drugs. There are 9 identical compounds in Phellodendron amurense and Coptis chinensis. Gardenia jasminoides and Scutellaria baicalensis, Phellodendron amurense and Scutellaria baicalensis, Phellodendron amurense and Scutellaria baicalensis all have three identical compounds. Scutellaria baicalensis and Coptis chinensis have two identical compounds. Gardenia jasminoides and Coptis chinensis share 1 same compound. 

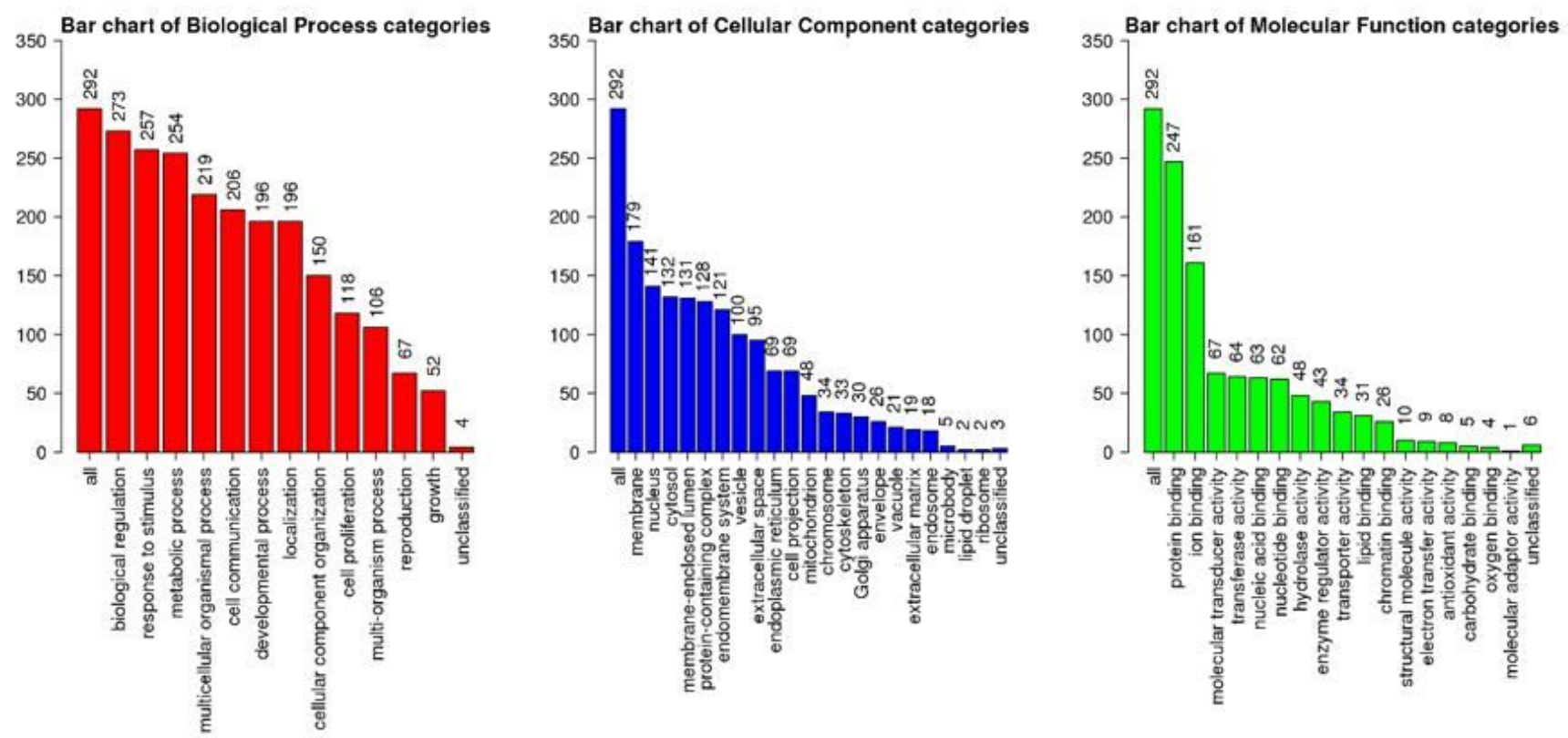

Figure 3

GO enrichment analysis of Huanglian Jiedu Decoction target Annotate the GO function of the active ingredient targets of HLJDD. The height of the bar graph represents the number of overlapping genes in the category. Correlation between biological regulation, stress response, and metabolic processes is high in biological processes (red). Among cell components (blue), the proportion of cell membrane, nucleus, and cytoplasmic matrix is relatively high; In molecular function (green), protein binding, ion binding, and molecular sensor activity have a great impact. 


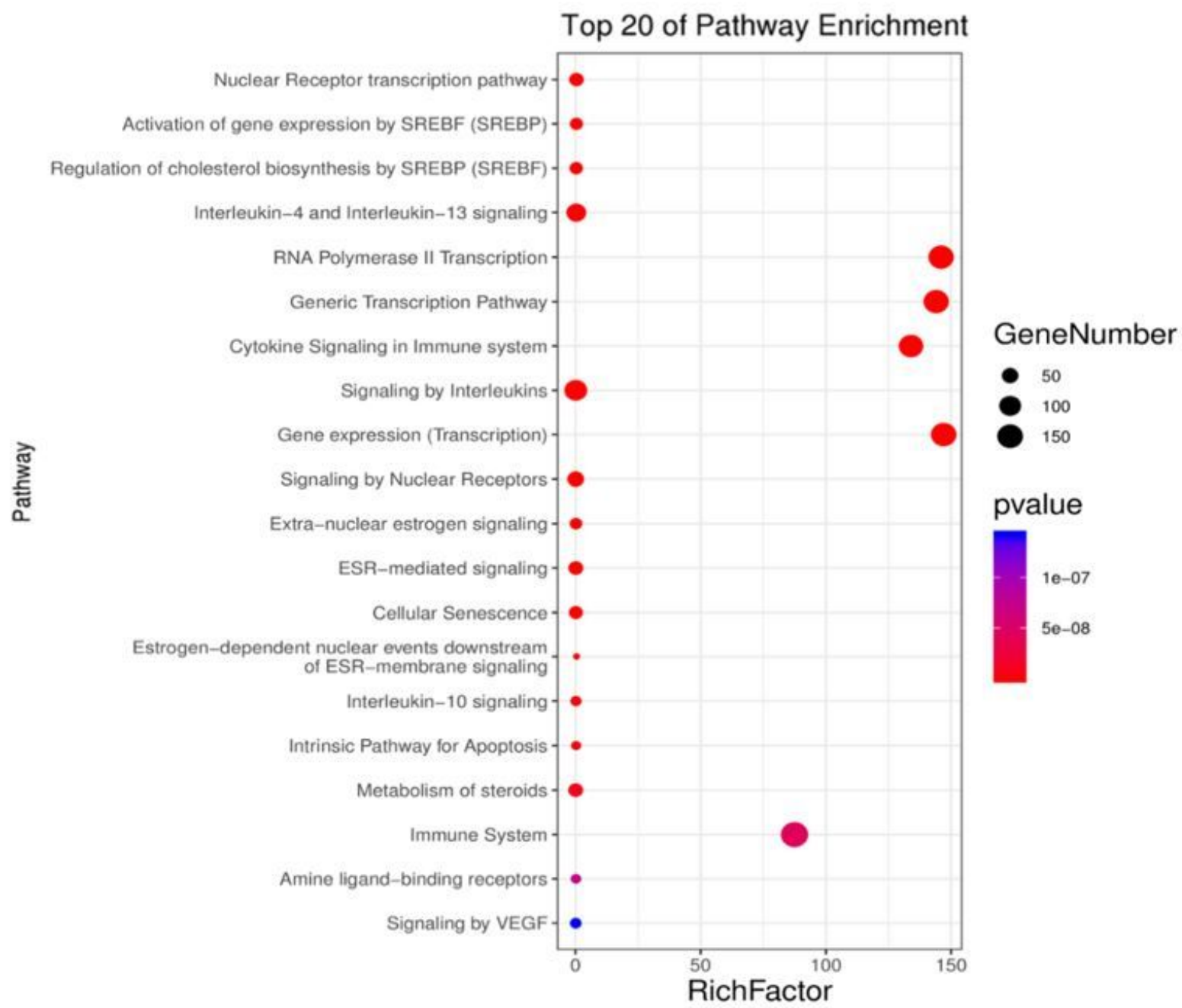

\section{Figure 4}

Visualization of KEGG enrichment pathway The first 20 signal pathways were obtained by Pathway analysis through reactome. The first 20 signal pathways were nuclear receptor transcription pathways, SREBF (SREBP) activated gene expression, SREBP (SREBF) regulation of cholesterol biosynthesis, IL-4 and IL-13 Signaling, RNA polymerase II transcription, universal transcription pathways, cytokine signaling in the immune system, interleukin signaling, etc. Visualize the results of enrichment analysis using Omicshare. 


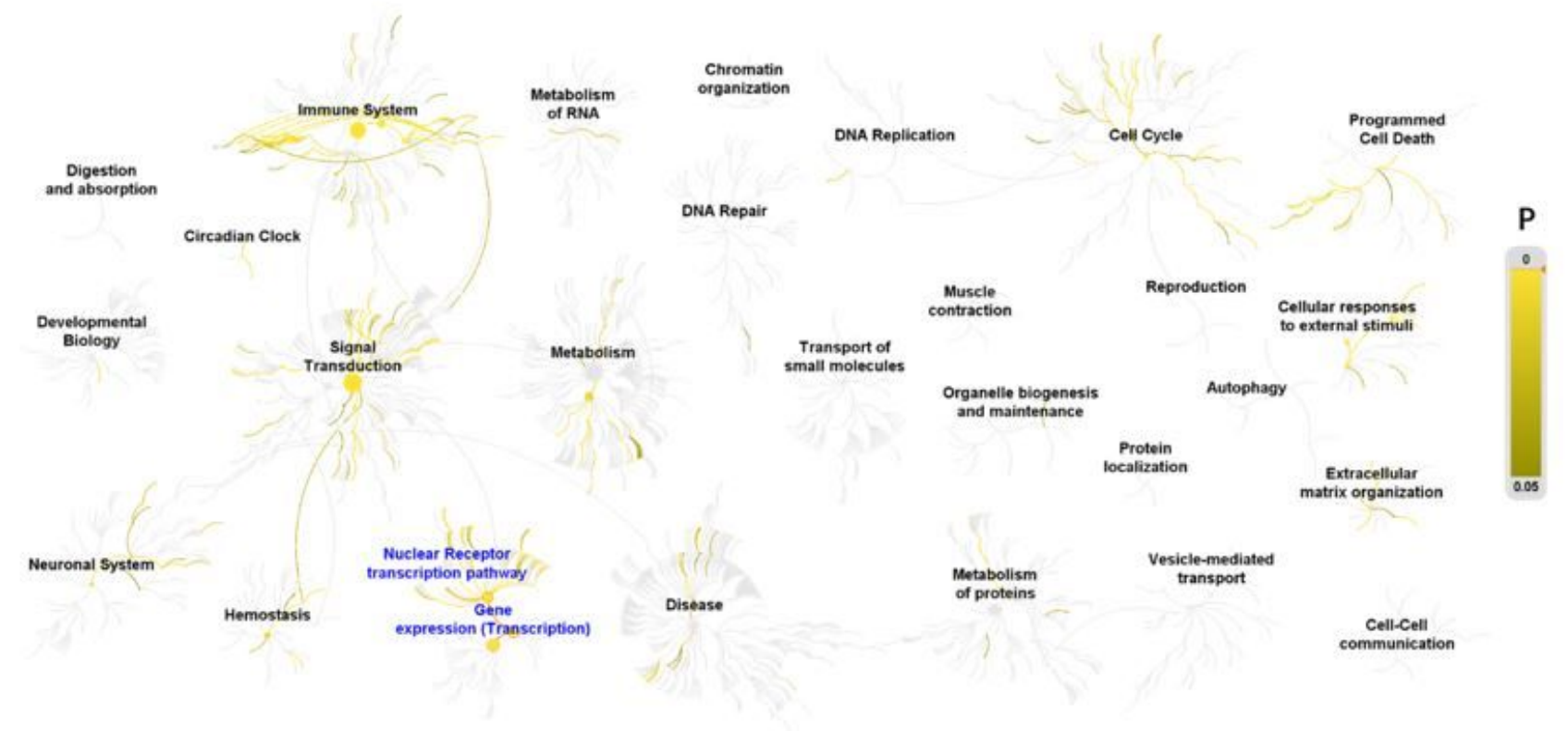

Figure 5

KEGG enrichment pathway annotation A total of 306 signal pathways were obtained through Pathway analysis by reactome $(P<0.05)$. The core targets in the network mainly involved the immune system, signal transduction, gene expression, programmed cell apoptosis, cell cycle, and cell response to external stimuli and so on. The rightmost color band indicates the main enrichment path, and the $P$ value gradually increases as the color deepens. The center of each part is the root of a top-level path. One step away from the center represents the next lower hierarchy. Yellow indicates the obvious expression of the path, and gray indicates the path without obvious expression. 


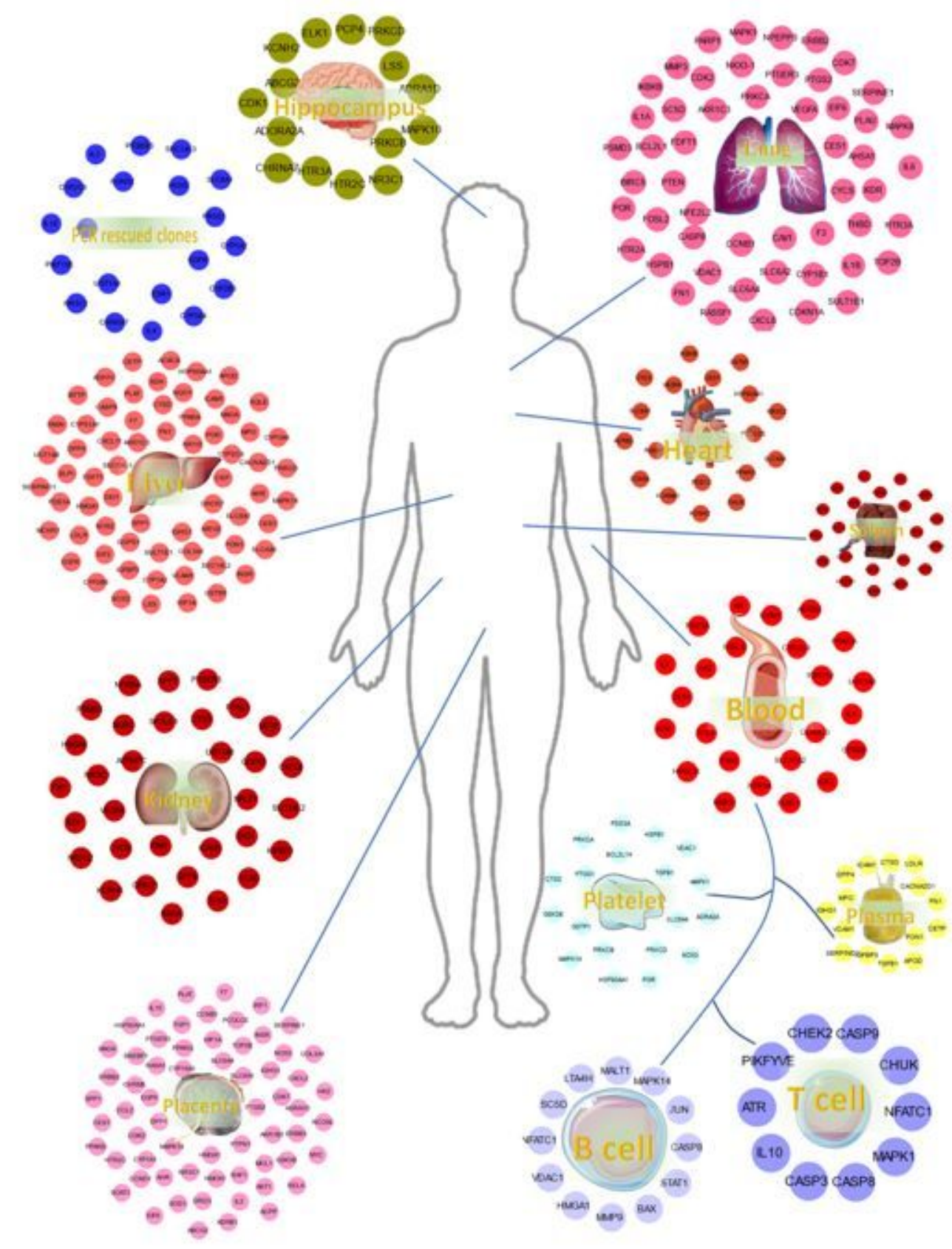

Figure 6

Tissue enrichment analysis of Huanglian Jiedu Decoction target As shown in Figure 7, tissue enrichment revealed that targets expression sites are mainly distributed in lung tissue, liver, and placenta, kidney, blood and involve a variety of immune cells, such as $T$ cells and B cells. 

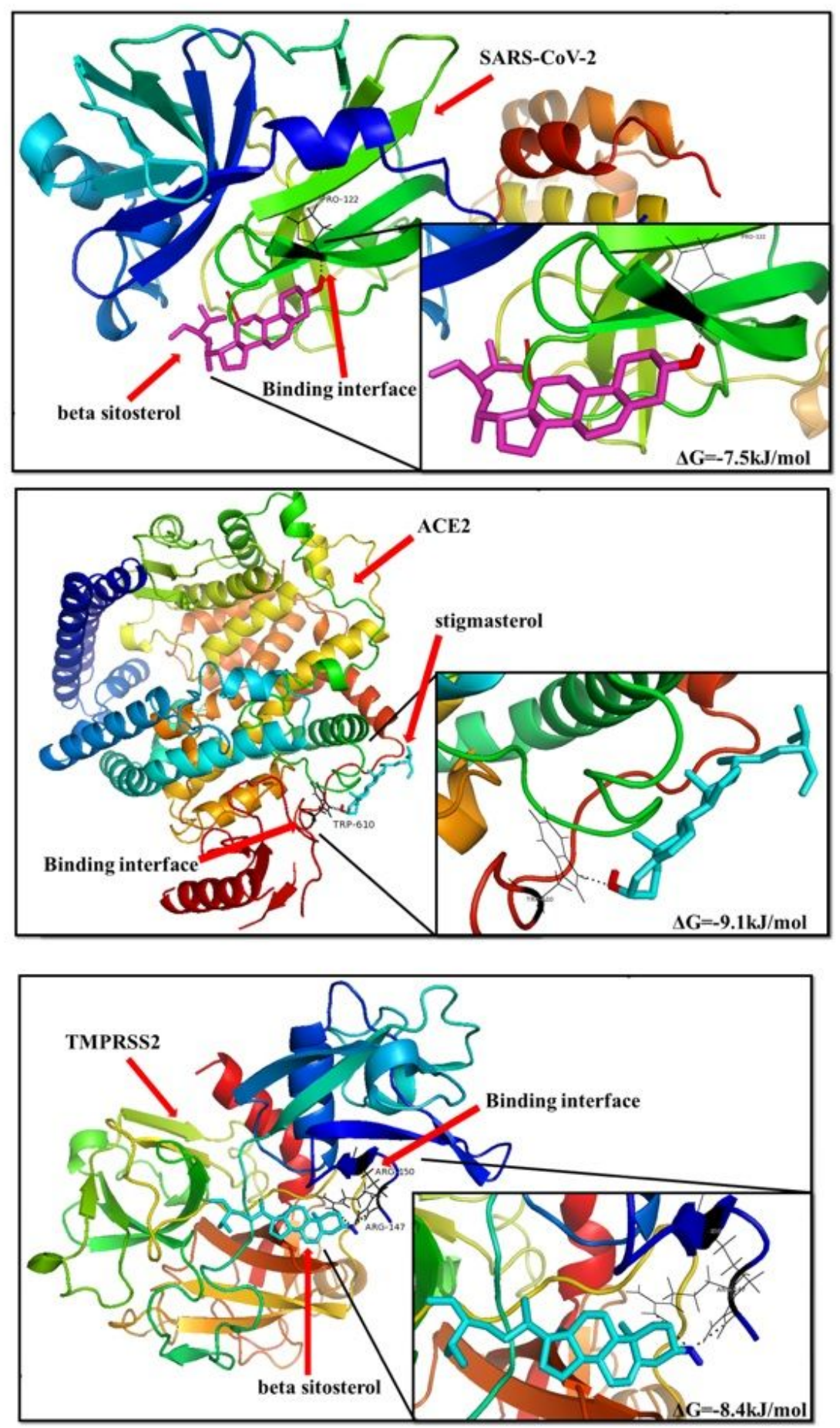

\section{Figure 7}

The Molecular Docking Diagram (the black part is the docking site) The autodock docking molecule SARSCoV-2 3CL hydrolase, ACE2, TMPRSS2 and stigmasterol, beta sitosterol ligand are used. The docking site is the black part. As shown in the enlarged part in the figure, the binding energy of ACE2 with stigmasterol was $-9.1 \mathrm{KJ} / \mathrm{Mol}$ and the binding energy of SARS-COV-2 3CL hydrolase and TMPRSS2 with beta sitosterol was $-7.5 \mathrm{KJ} / \mathrm{Mol}$ and $8.4 \mathrm{KJ} / \mathrm{Mol}$ respectively. 


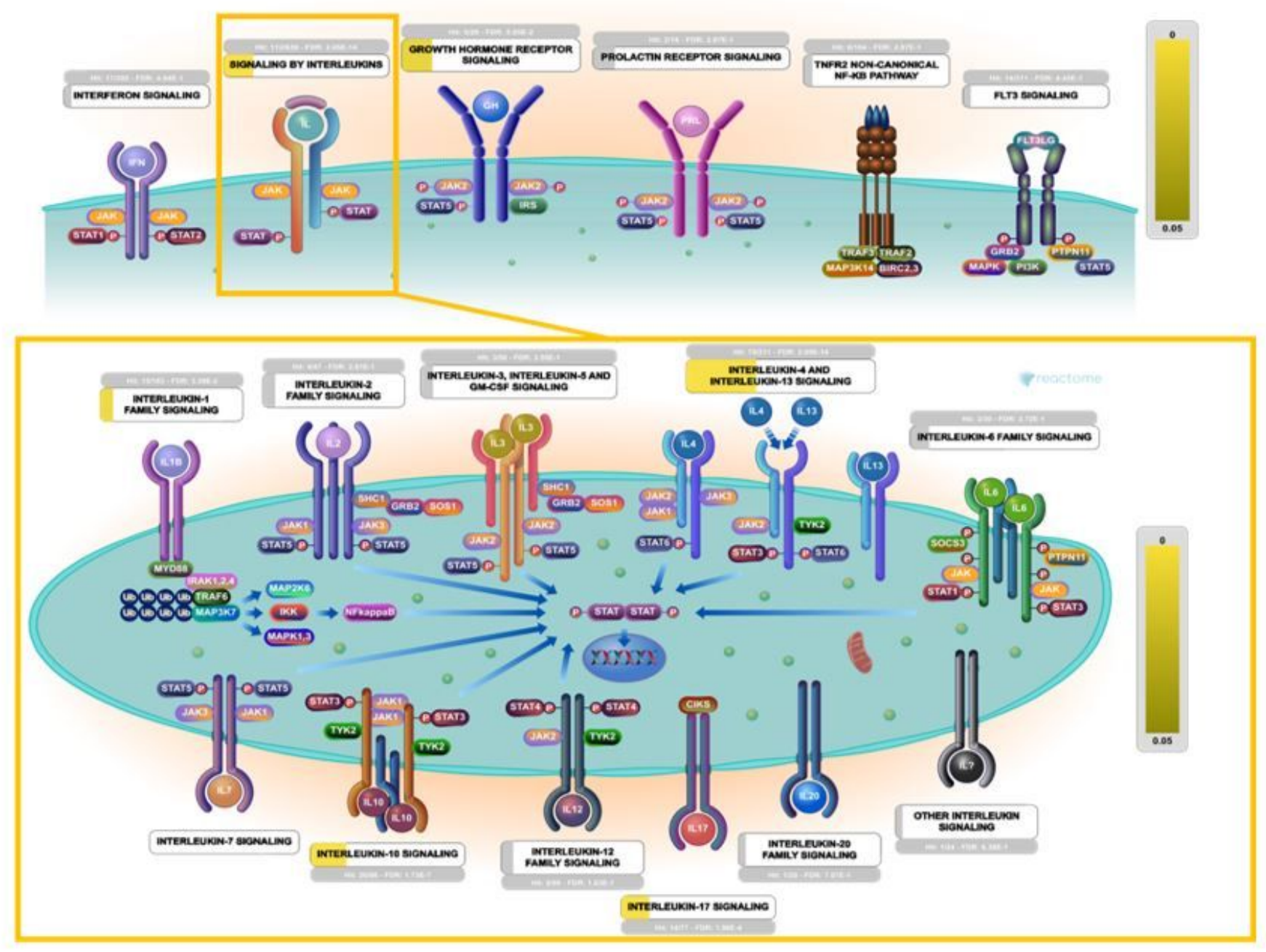

Figure 8

KEGG pathway predicts the mechanism of HLJDD intervention in interleukin signaling in the immune system The core targets are mainly interferon signaling, interleukin signaling, growth hormone receptor signaling, prolactin receptor signaling, TNFR2 non-canonical NF-KB pathway, and FLT3 signaling in cytokine signaling in the immune system. The interleukin signaling pathway mainly involves IL-1 family signaling, IL-2 family signaling, IL-4 and IL-13 signaling, IL-3,IL-5 and GM-CSF signaling, IL-6 family signaling, IL-7 signaling , IL-10 signaling, IL-12 family signaling, IL-17 signaling, and IL-20 family signaling. The far right color band indicates that the $\mathrm{P}$ value gradually increases as the color deepens. 